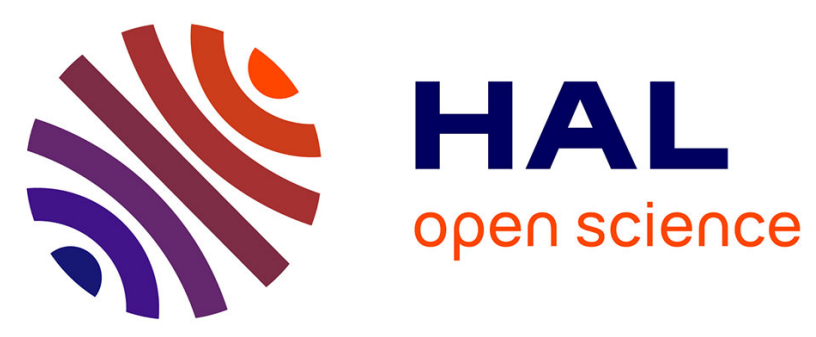

\title{
Technical innovations during the recent Solutrean in the southwest of France: Recognition of heat treatment of chert and estimation of heating temperatures based on the example of Le Piage (Lot, France)
}

Julie Bachellerie, Caroline Renard, Patrick Schmidt

\section{To cite this version:}

Julie Bachellerie, Caroline Renard, Patrick Schmidt. Technical innovations during the recent Solutrean in the southwest of France: Recognition of heat treatment of chert and estimation of heating temperatures based on the example of Le Piage (Lot, France). Journal of Archaeological Science: Reports, 2019, 27, pp.102001. 10.1016/j.jasrep.2019.102001 . hal-02320713

\section{HAL Id: hal-02320713 \\ https://hal.science/hal-02320713}

Submitted on 7 Jan 2021

HAL is a multi-disciplinary open access archive for the deposit and dissemination of scientific research documents, whether they are published or not. The documents may come from teaching and research institutions in France or abroad, or from public or private research centers.
L'archive ouverte pluridisciplinaire HAL, est destinée au dépôt et à la diffusion de documents scientifiques de niveau recherche, publiés ou non, émanant des établissements d'enseignement et de recherche français ou étrangers, des laboratoires publics ou privés. 
Technical innovations during the recent Solutrean in the southwest of France: recognition of heat treatment of chert and estimation of heating temperatures based on the example of Le Piage (Lot, France).

Julie Bachellerie ${ }^{\mathrm{a}}$, Caroline Renard ${ }^{\mathrm{a},}$, Patrick Schmidt ${ }^{\mathrm{b}, \mathrm{c}}$

a TRACES - UMR5608, Université de Toulouse Jean-Jaurès, Maison De La Recherche, 5 Allée Antonio Machado, 31058 TOULOUSE, France

${ }^{\mathrm{b}}$ Eberhard Karls University of Tübingen, Department of Early Prehistory and Quaternary Ecology, Schloss Hohentübingen, 72070 Tübingen, Germany.

${ }^{\mathrm{c}}$ Eberhard Karls University of Tübingen, Department of Geosciences, Applied Mineralogy, Wilhelmstraße 56, 72074 Tübingen, Germany.

\title{
Corresponding author:
}

Julie Bachellerie (Orcid: 0000-0001-5675-0255)

Mail: julie.bachellerie@etu.univ-tlse2.fr

Full postal address : Bureau des doctorants, Laboratoire TRACES - UMR 5608 Université Toulouse Jean Jaurès Maison de la Recherche 5, allée Antonio Machado 31058 TOULOUSE Cedex 9

Tel: +33648201902

\begin{abstract}
The Solutrean technocomplex is characterized by the use of innovative techniques for stone tool knapping during the Upper Palaeolithic. These processes include the development of pressure retouch and heat treatment of silica rocks. These innovations remain unprecedented at the scale of the recent European Paleolithic. The aim of our analysis is to acquire new information on the application of heat treatment, by investigating the heating technique and the lithic chaîne opératoire in which this treatment occurs. Macroscopic observations of the material combined with an infrared spectroscopic analysis of 69 archaeological samples provide new data on heat treatment in the Solutrean lithic series of Le Piage (Fajoles, Lot). Raw materials were heated in controlled conditions and to temperatures of $250-300^{\circ} \mathrm{C}$. We also found that only leaf-shaped pieces were heat-treated at Le Piage. Part of the results obtained by infrared spectroscopy reveal discrepancies with macroscopic observations. These data raise questions concerning the validity of common macroscopic criteria used for recognising heat treatment and shed light on some of the choices made by Solutrean groups.
\end{abstract}

Keywords: lithic points, lithic technology, pyrotechnology, Infrared spectroscopy, Upper Palaeolithic, Technical innovations 


\section{Introduction}

The upper Solutrean (circa 24-23.5/23 ka cal BP) saw the development of an original and diversified hunting toolkit ${ }^{1}$. The production of this toolkit required particular care and high levels of technical and economic investments (among others, Pelegrin, 2013; Renard, 2010; Renard and Ducasse, 2015; Renard and Geneste, 2006; Schmidt, 2015). This went with the appearance of two new techniques identified throughout the Solutrean geographical area: pressure retouch, and heat treatment of silica rocks.

Heat treatment modifies the mechanical properties of silica rocks. It is known to improve knapping quantity and the cutting edges of the finished object were found to be sharper (see among others, Anderson, 1978; Boix Calbet, 2012; Collins and Fenwick, 1974; Crabtree and Butler, 1964; Domanski and Webb, 1992; Flenniken and Garrison, 1975; Inizan et al., 1976; Léa et al., 2012; Mandeville, 1973; Masson, 1981; Purdy, 1974; Purdy and Brooks, 1971; Roqué-Rosell et al., 2011; Schmidt, 2011; Terradas and Gibaja, 2001; Tiffagom, 2006; Torchy, 2013, Schmidt et al, 2018b). In France, Solutrean heat treatment was identified in the 1960s-70s when heat-treated laurel-leaf points were found on the sites of Laugerie-Haute and Le Placard (Bordes, 1967, 1969; Collins, 1973; Inizan et al., 1976). The recognition of heat treatment in Solutrean contexts of the Iberian Peninsula occurred later, but mentions of it are now more abundant there than in France. In Spain, in addition to the site of La Cueva de Ambrosio (Andalusia), where heat treatment may have been used (Ripoll López et al., 1997), clear evidence of heat treatment for laurel-leaf shaping, and more occasionally, on barbed and tanged points, were observed at the Cueva de Parpalló (Gandia) (Tiffagom, 1998, 2006). In Portuguese Estremadura, heat treatment was described the sites of Caldeirão, Vale Almoinha, Lapa do Anecrial, Monte da Fainha, Buraca Grande, Lagar Velho and Salemas Cave (Almeida et al., 2006; Aubry and Almeida, 2013; Zilhão, 1997). There, heat treatment was used for shaping of bifacial preforms and laurel-leaf points found in mid or recent Solutrean levels. On the Iberian Peninsula in general, heat treatment does not appear to be systematically associated with a subsequent stage of pressure retouch (Zilhão, 1997; Tiffagom, 2006). At French Solutrean sites heat treatment is still only poorly characterized and data remain sparse. It has rarely been studied in its techno-economic context and today we still know very little about its extent and the heating technique(s) used.

In this paper, we present new data on Solutrean heat treatment by identifying the process and used heating temperatures. Our study is based on macroscopic observations and infrared spectroscopic analyses of Solutrean lithic artefacts from the site of Le Piage (Lot, France); (fig.1). A technological characterization of the archaeological samples was also carried out to determine the stages of the shaping chaîne opératoire during which heat treatment took place.

\section{Materials and Methods}

\subsection{Archaeological context}

\footnotetext{
${ }^{1}$ In South-western France, two regional complexes have been identified on the basis of the style of lithic points: the first, the "Atlantic" type, is widespread from North Aquitaine to the western central France, and the second is confined to the Pyrenees and the Vasco-Cantabrian extension and is made up of shouldered Vasco-Cantabrian type points and points with concave bases.
} 


\section{Site and stratigraphy}

The first field operations at Le Piage (Fajoles, Lot) in 1958 was directed by F. Champagne and R. Espitalié and yielded a unique "Solutrean-Badegoulian" layer extending over the whole excavated surface (Champagne and Espitalié, 1981) (fig.1). This layer, called C-E, consisted of abundant material in an homogeneous sedimentary complex, interpreted as resulting from a mix of Solutrean and Badegoulian artefacts (i.e. combined presence of shouldered Solutrean points : fig. $1, \mathrm{n}^{\circ} 5$ and 6 , and Badegoulian raclettes: fig. $1, \mathrm{n}^{\circ} 7$ to 12 ). The initial hope of finding a sterile layer between layers $\mathrm{C}$ and $\mathrm{E}$, that would allow to distinguish two clearly disconnected complexes, was soon abandoned. J.-G. Bordes and F. Le Brun-Ricalens picked up work at the site in $2004^{2}$. The discovery of remaining sediments, not excavated by the site's discoverers, allowed for working on the "Solutrean-Badegoulian" layer of Le Piage. Between 2006 and 2008, the excavation of strips of layer C-E at the top of the "north remainder" confirmed that Solutrean and Badegoulian industries were mixed at the site, as previously observed by F. Champagne and R. Espitalié. Nonetheless, fieldwork in other sectors of Le Piage yielded other Solutrean-Badegoulian evidence indicating diverse "physically" disconnected assemblages; fig. 1.C.

\section{The Piage Solutrean assemblage}

At Le Piage, the Solutrean toolkit consists mainly of fragmented laurel-leaf points $(n=102)$ and shouldered points $(n=73)$, suggesting the presence of an Upper Solutrean (fig. 1.B). A large quantity of shaping flakes shows that laurel-leaf shaping activities were conducted on site. Most of the shaping flakes are made from fine translucent Tertiary lacustrine chert, most likely coming from the plateau de Bord in Domme, about $10 \mathrm{~km}$ from the site. This formation results from a silicification of palustrine sediments (i.e. the rocks contain gastropods (Nystia duchasteli), charophyte gyrogonites and specific fish scales (Morala, 2007; Morala, 2017). At the plateau de Bord, this chert can be found as nodules and plates in secondary position within decalcification clays. It has a fine texture, but its knapping quality is moderate, because of many irregularities and microcracks, most likely caused by frost (Gèze, 1977; Morala, 2007: 276; Morala, 2017; Turq and Morala, 2013; Vigneaux, 1975). Despite a difficult taphonomic context, the quantity and diversity of Solutrean material brought to light at Le Piage enables us to investigate certain aspects of the heating technique used.

\subsection{Macroscopic recognition of heat-treatment}

Since the 1960s several experiments have been carried out on the effects of heat treatment of silica rocks (see among others, Crabtree and Butler, 1964; Inizan et al., 1976; Purdy and Brooks, 1971). Heat treatment causes mechanical transformations of silica rocks (for example flakeability) (Schmidt et al., 2018b). However, it also causes different types of visible alteration. According to experimental observations it can involve reddening and/or whitening of the surface and the appearance of gloss on knapped fracture surfaces. These criteria are currently used for the macroscopic detection of heat treatment in archaeological context. (see among others, Collins and Fenwick, 1974; Crabtree and Butler, 1964; Domanski and Webb,

\footnotetext{
${ }^{2}$ The reopening of the excavations were motivated by scientific issues on the emergence of anatomically modern humans and their relationship with the last Neanderthals.
} 
1992; Flenniken and Garrison, 1975; Inizan et al., 1976; Mandeville, 1973; Masson, 1981; Purdy, 1974; Purdy and Brooks, 1971; Terradas and Gibaja, 2001).

(i) Reddening of the rock can occur above $200-300^{\circ} \mathrm{C}$. It has been described to be caused by the transformation of goethite to hematite and is not systematic because it depends on the concentration of these iron oxides in the rock (among others, Domanski and Webb, 1992; Masson, 1981; Purdy and Brooks, 1971; Schindler et al., 1982; Tiffagom, 2006). Reddening is thus an inconsistent phenomenon and does not necessarily coincide with a structural or mineralogical modification of the material.

(ii) Surface whitening occurs at higher temperatures. The whitish aspect corresponds to the appearance of internal microcracks created by the sudden evacuation of structural water (Schmidt, 2014). It can appear at temperatures of about $300-400^{\circ} \mathrm{C}$ or much higher. In this case, the rock becomes opaque. However, whitening is not a good criterion for identifying heat treatment because it rather indicates "overheating" (i.e. internal micro-cracking renders the material less suitable for knapping).

Thus, the identification of both reddening and whitening do not allow to reliably identify intentional heat treatment. They can also be caused by unintentional burning or taphonomic processes.

(iii) Heat treatment can only be considered a deliberate action if the object is knapped afterwards (including shaping, "debitage" or retouch). The result of such post-heat treatment knapping is surface gloss. It is caused by changing fracture pattern due to modified mechanical properties of the material (Schmidt et al., 2018b) and is therefore only visible if the artefact is worked after heating (Crabtree and Butler, 1964; Domanski and Webb, 1992; Inizan et al., 1976; Masson, 1981; Purdy and Brooks, 1971). The intensity of this gloss depends mainly on the temperature reached during heating but also on the type of rock (Inizan et al. 1976; Masson, 1981; Domanski and Webb, 1992). Gloss has been described to appear at a later stage and to be less obvious in bioclastic or heterogeneous rocks (Masson, 1981). It is best to identified when associated with pre-heating fracture scars that do not show the same gloss. In this case, such gloss contrast is a reliable macroscopic criterion for recognizing heat treatment (Collins et Fenwick 1974; Inizan et al. 1976; Tiffagom 1998). In the absence of this contrast, glossy surfaces can only be determined by the direct comparison of the surface aspect with reference artefacts. This is possible for homogeneous raw materials (Léa et al., 2012; Delagnes et al., 2016).

\subsection{Archaeological and geological samples}

To select suitable samples for our analyses, we conducted macroscopic observations of the Solutrean lithic material from Le Piage (fig. 1A, $n^{\circ} 1$ to 6 and B). As both Solutrean and Badegoulian artefacts occur intermixed at the site, we only examined shaping flakes and lithic equipment that is unambiguously Solutrean. We chose to only analyse artefacts made from the Tertiary translucent chert described above. The observed series are from excavations carried out by F. Champagne and R. Espitalié, on one hand and J.G. Bordes and F. LebrunRicalens, on the other. They are curated at the National Archaeology Museum (SaintGermain-en-Laye), at the Fajoles excavation depot and at the University Jean Jaurès Toulouse. During macroscopic inspection, only eighteen heat-treated artefacts on the all 
Solutrean assemblage were identified and selected on the basis of gloss contrast. We also selected twelve pieces among others interpreted as overheated. Thirty-nine flakes were selected that did not show any proxies of heating.

We separated our material $(n=69)$ into three categories on the basis of the heating proxies described in section 3.2:

(1) TEST NH (TEST-Hypothesis Not Heated): samples with no macroscopic indicators of heating, presumed to be unheated $(n=39)$. These are 39 shaping flakes (fig. 2$)$.

(2) TEST HT (TEST- Hypothesis Heated): pieces ( $n=12)$ with macroscopic indicators of overheating (pits, marked reddening, cracking) or strong gloss (but without gloss contrast). On the basis of macroscopic markers alone, it cannot be decided whether these pieces were intentionally heated or not.

(3) CALIB HT: heat-treated pieces with gloss contrast ( $n=18$; fig. 3). Although little doubt on whether they were heat-treated persist, they nonetheless allow to estimate the temperatures applied during heating.

We have conducted a technological characterisation of these 69 artefacts. Shaping flakes contain crucial information on the techniques used and also on the heating process. Their technological description allows to determine the chronological position of heat treatment within the bifacial shaping sequence.

For infrared analysis, archaeological samples must be compared with geological samples made from the same raw material (coming from the same outcrop). The closest correspondence to our artefact assemblage is Tertiary translucent chert from the plateau de Bord at Domme, at about $10 \mathrm{~km}$ from the site (J.-G. Bordes and S. Caux, pers. com.). We made a reference collection of unheated and experimentally heat-treated flakes from this chert.

\subsection{Determination of heating temperatures by NIR}

The theoretical background and detailed experimental setup of the conducted near infrared spectroscopy (NIR) are explained in Schmidt et al. (2013), and only information considered to be absolutely necessary for understanding the method are repeated here.

Transformations of silica rocks during heating are caused by the progressive disappearance of silanol $(\mathrm{SiOH})$. This reaction leads to a gradual reduction of the intergranular porosity network by the progressive formation of new Si-O-Si bonds, which correspond to a "homogenization" of the mechanical properties (Schmidt et al., 2018b). The reaction can be formulated as:

$$
\mathrm{Si}-\mathrm{OH}+\mathrm{HO}-\mathrm{Si} \rightarrow \mathrm{Si}-\mathrm{O}-\mathrm{Si}+\mathrm{H}_{2} \mathrm{O}
$$

NIR can trace this reaction through the average hydrogen bond strength. The analyses involve the transmission of infrared rays through the samples. The resulting absorption spectrum presents a combination band near $4300-4600 \mathrm{~cm}^{-1}$ caused by the $\mathrm{SiOH}$. Measurement of the transmission can be made through the thin part of lithic artefacts (typically, near the cutting edge) and remain non-destructive. The shape of the $\mathrm{SiOH}$ absorption band (measured as the 
ratio between the linear absorbances at $4545 \mathrm{~cm}^{-1}$ and $4469 \mathrm{~cm}^{-1}$ (the short notation for the ratio being $4545 / 4469 \mathrm{~cm}^{-1}$ ) is partly influenced by the quantity of water held in the open pore space of the samples (fig. 4). The mechanism behind this is the chemical interaction of this pore water with surface $\mathrm{SiOH}$ (hydrogen bonding). More pore water causes a shift to lower frequencies, while less pore water causes a shift to higher wavenumbers (Schmidt et al., 2011). The shape of the band is therefore an indirect measure of the quantity of water held in open pores and, if all available pore space is completely filled with water, also of the volume of open pore space of the sample itself. When chert is heat-treated, it gradually loses such open pore space (Roqué-Rosell et al., 2011; Schmidt et al., 2012; Milot et al., 2017). Schmidt et al.'s (2013) method aims at detecting past heating through the measurement of a sample's pore space with respect to the pore space of another sample of the same rock type that was clearly never heated. The two samples compared in this way, the one tested for past heating and the reference, must undergo an identical protocol that allows for total filling of their open pore space with deionized or distilled $\mathrm{H}_{2} \mathrm{O}$. A higher value of the $4545 / 4469 \mathrm{~cm}^{-1}$ ratio in the tested sample, as compared with the same ratio for the reference sample, indicates that the former was subjected to heating in the past. The heating temperature can be estimated by combining these measurements with measurements of experimentally heat-treated reference samples of the same rock. A reference sample is progressively heated to different temperatures, rehydrated using the same protocol and then analysed for its $4545 / 4469 \mathrm{~cm}^{-1}$ ratio after each temperature step. The comparison between the ratio values of the archaeological samples and the ratio of the reference allows to estimate the temperature range to which the archaeological sample was heated.

In order to estimate the heating temperature of the archaeological samples, a calibration series was set up: nine geological samples successively underwent seven temperature steps of 150 , $200,250,275,300,325$ and $350^{\circ} \mathrm{C}$. Before the first heating stage, samples were placed in an oven at $110^{\circ} \mathrm{C}$ for $48 \mathrm{~h}$, then rehydrated in deionized water at $40^{\circ} \mathrm{C}$ for $48 \mathrm{~h}$, then a spectrum was acquired to calculate the hydration ratios of the material before heating. They were then heated to $150^{\circ} \mathrm{C}$, rehydrated again for $48 \mathrm{~h}$ at $40^{\circ} \mathrm{C}$ in an oven, then a spectrum was recorded. This protocol was repeated for each heating temperature. An electric oven was used for heating, so that the time and speed of temperature increase could be controlled: $1^{\circ} \mathrm{C} / \mathrm{min}$. Most of the structural and crystallographic transformations occur after $1 \mathrm{~h}$ at maximum temperature (Schmidt et al., 2016). However, the geological reference samples were maintained at maximum temperature for $2 \mathrm{~h}$.

Likewise, archaeological samples were first dehydrated at $110^{\circ} \mathrm{C}$ for $48 \mathrm{~h}$ in order to "empty" open porosity water. The artefacts were then rehydrated in deionized water at $40^{\circ} \mathrm{C}$ for $48 \mathrm{~h}$. The spectra were recorded through the thinnest parts of each sample (between 0.5 and $4 \mathrm{~mm}$ maximum thickness).

\section{Analytic equipment}

The analyses were carried out at the University of Tübingen using an Agilent Cary 660 infrared spectrometer equipped with a DTGS detector. Spectra were recorded between 7000 and $2000 \mathrm{~cm}^{-1}$ with a resolution of $8 \mathrm{~cm}^{-1}$ and a mirror oscillation frequency of $12.5 \mathrm{kHz}$. Spectral acquisitions were repeated between 100 and 300 times in order to minimise noise in the spectra. IR light (analysis zone with a diameter of $8 \mathrm{~mm}$ ) was directly transmitted through 
the samples, which were vertically mounted in the spectrometer analysis chamber. Absorption spectra were analysed with Bruker OPUS software.

The measurement error was set at \pm 0.01 (taken from Schmidt et al., 2013). The adequacy of this error was then confirmed by the dispersion of the ratio values obtained from the geological reference samples before heating (fig. 5). This reflects the heterogeneity of the analysed rock regarding the distribution of silanol within the rocks.

\section{Results}

\subsection{Infrared spectroscopic analyses}

An example of a NIR spectrum is presented in figure 4. Results obtained on geological samples are summarized in table 1. Hydration ratio values are presented as boxplot diagram for each temperature step in Fig. 5.

\section{Reference collection}

Upon heating, the $\mathrm{SiOH}$ absorption band shifts to higher wavenumbers. Hydration ratio values thus increase progressively (fig $5 ;$ tab.1). This progressive increase of the ratio value is associated with increasing data dispersion. No significant band-shape change is visible below $150^{\circ} \mathrm{C}$, and till $250^{\circ} \mathrm{C}$ the scattering of ratio values overlaps with some of the unheated ratio values. Thus, NIR cannot unambiguously identify heat treatment below $250^{\circ} \mathrm{C}$. This is marked as a grey zone of uncertainty in figure 7 . Above $300^{\circ} \mathrm{C}$, ratio values are higher than unheated values. At higher temperatures, we also noted more accidents: pot-lids and cracking were observed on three geological samples upwards of $325^{\circ} \mathrm{C}$. No spectra were acquired for these samples.

\section{Archaeological samples}

The hydration ratio values obtained for the archaeological samples are represented in figure 6.a. The three macroscopic groups are not clearly differentiated by this analysis. Samples from the TEST NH group yielded ratio values between 0.751 and 0.811 . Pieces from the TEST HT and CALIB TH groups yielded similar values between 0.762 and $0.850 \pm 0.01$. Comparing these results with ratio values from the reference collection (fig. 6.b) suggests that artefacts with values above 0.785 underwent heating. Out of the 69 samples, 30 appear to have been heated (42.9\%). The remaining 39 archaeological artefacts present a value below 0.78. No information can be inferred from these pieces (i.e. either they were not heated or they may have been heated to low temperatures).

Comparing the ratio values of the artefacts identified as being heated with the temperature thresholds produced by our reference collection allows to estimate the heating temperature of the artefacts (Fig. 7). Based on this estimation, archaeological heating temperatures lie between 250 and $300^{\circ} \mathrm{C}$ for 18 samples, between 300 and $325^{\circ} \mathrm{C}$ for eight samples and between 325 and $350^{\circ} \mathrm{C}$ for three artefacts.

\subsection{Technological characterization of archaeological samples}

Apart from some flakes that result from correcting knapping accidents, most of the shaping flakes with evidence of heat treatment are not very thick (on average $2.6 \mathrm{~mm}$ ). Apart from a few exceptions $(\mathrm{N}=3)$, it is impossible to measure the maximum dimensions of these flakes 
due to their very fragmentary state. No residual cortical zones were observed on the upper face of these flakes and their profile is relatively curved. On pieces where the proximal part is preserved, butts are prepared by faceting and nearly systematically by careful abrasion - or grinding - of the ledge in order to isolate and consolidate the impact point (fig. 6). We have observed gloss on flakes butts, which implies that the preparation generally occurs after the heat treatment stage. In at least two cases, no preparation of the butt after heating was observed. Percussion is tangential and angles are very closed (angles de chasse of 40 to $60^{\circ}$ ). A soft organic hammer seems to have been used for most of the shaping, consisting of thinning phases. The use of a mineral hammer is more likely for some flakes associated with correcting knapping accidents. Careful butt preparation suggests an advanced stage in the shaping chaîne opératoire. Indeed, investment in removal preparation seems to generally increase as shaping advances (Walter et al., 2013). Among the tools, we identified four fragments of clearly heat-treated bifacial pieces.

\section{Discussion}

\subsection{Identification of heating and temperature ranges}

Infrared spectroscopic analyses did not confirm all of our initial hypotheses based on macroscopic observations. Due to data dispersion, the results for the archaeological material should be interpreted with caution.

The archaeological samples for which we identified gloss contrast (CALIB HT) did not all yield values beyond the indeterminate zone in Fig. 6. Thus, no deductions can be made for these pieces and them being heated or not cannot be confirmed. For the other artefacts of this group $(n=12)$, ratio values indicate that they were heated to temperatures between $250^{\circ} \mathrm{C}$ and $300^{\circ} \mathrm{C}$ (a single piece was subjected to higher temperatures, close to $325^{\circ} \mathrm{C}$ ). This, rather homogeneous range of temperatures, as compared to significantly larger temperature ranges recorded in on other heat treatment-bearing assemblages (in that case Mesolithic, see: Schmidt et al 2017) indicates that Solutrean heat treatment at Le Piage was a rather wellcalibrated technique.

The TEST NH group produced values below 0.785 for 29 pieces. This is in agreement with our initial macroscopic estimates, although the NIR method's uncertainty does not preclude that some of them were actually heat-treated to temperatures below $250^{\circ} \mathrm{C}$. Pieces with values above $0.785(n=11)$ are in disagreement with our initial hypothesis. The spectroscopic study shows that these pieces were heated to the same range of temperatures as pieces from the CALIB HT group (that show gloss contrast): between $250^{\circ} \mathrm{C}$ and $300^{\circ} \mathrm{C}$.

Most of the artefacts of the TEST HT group appear to have been heated. Samples with estimated temperatures of about $325-350^{\circ} \mathrm{C}(\mathrm{n}=3)$ also present macroscopic traces of "overheating": pot-lids, whitening and micro-cracks. The results obtained for these pieces (hydration ratio > 0.82) may be attributable to post-depositional heating.

\subsection{Potential sources of uncertainty}

One potential source of uncertainty of our NIR analysis is that post-depositional heating would also cause a signal indicative of heat treatment. However, this hypothesis appears 
unlikely because the range of detected temperatures is close to the temperatures previously proposed for intentional heat treatment (Gibaja and Clemente, 1997; Griffiths et al., 1987; Inizan et al., 1976; Mandeville, 1973; Masson, 1981; Purdy, 1974) and their homogeneity (ranging mainly from $250^{\circ} \mathrm{C}$ to $300^{\circ} \mathrm{C}$ ).

Another uncertainty may result from our identification of the correct raw material corresponding to the artefacts and from heterogeneity within the materials. If we chose the wrong geological chert for comparison with artefacts in our NIR study, the temperature estimations might be slightly off. Tertiary chert from lacustrine formations can be found throughout the Massif Central. These lacustrine microenvironments are not easily distinguished one from another as formation environments are very similar (Caux, 2015; Demars, 1998; Gèze, 1977; Morala, 2017; Turq, 2000; Turq and Morala, 2013; Vigneaux, 1975). It is difficult to define specific facies for each of them, which considerably complicates the precise identification of the material. At Le Piage, the presence of a chert outcrop less than $10 \mathrm{~km}$ away from the site is a good indicator, although it is difficult to confirm the provenance of the flint used (J.-G. Bordes, pers. com.). This potential problem cannot be addressed based on the available data and only future works on the exact provenance of the Piage Tertiary chert will shed light on the matter.

The plateau de Bord chert studied here presents numerous irregularities and different surface conditions within the same block. Also, its macroscopic transformations during heating vary significantly from block to block: the degrees of reddening or overheating accidents. Intersample heterogeneity may explain the dispersion of ratio values of the geological material. These findings on the heterogeneity between blocks also shed new light on the temperature determination of Schmidt and Morala (2018a) that had used a similar chert. They had used only one geological reference sample to establish a calibration curve for their heating temperature estimation. Dispersion of the ratio values in this calibration curve, as observed here, was therefore not visible in their study, falsely suggesting higher precision. Their temperature estimation must therefore be interpreted with slightly greater errors than described in their paper.

\subsection{The limits of macroscopic observations for identifying heat treatment}

We found discrepancies between our initial hypotheses based on macroscopic criteria and our NIR study. Also, surface whitening and reddening of the rock do not occur systematically and are not a result of structural modifications. Only gloss is a good indicator of heat treatment but our results raises questions about the identification of heated pieces in archaeological collections in the absence of gloss contrast. Without reference material or mat pre-heating fracture scars on the same artefact, surface gloss is difficult to identify, especially when raw material texture is extremely translucent, as is the case for thin shaping flakes. Our macroscopic identification criteria may not be fully adapted to artefacts made of Tertiary translucent chert.

During a bifacial shaping experiment replicating a laurel-leaf from Laugerie-Haute, M.B. Collins came to a similar conclusion after identifying only 30 flakes with contrast gloss, out of 62 flakes detached after heat treatment, producing 54\% of undiagnostic post-heating products (Collins, 1974). Heat treatment related data from the African Middle Stone Age (see 
among others Schmidt et al 2015, Schmidt and Högberg 2018; Delagnes et al 2016) also found that samples with gloss contrast often account for less than $30 \%$ of all heated debitage.

Thus, the number of heat-treated Solutrean artefacts in archaeological assemblages may actually be underestimated if only macroscopic observations are conducted.

\subsection{Interweaving between NIR analysis and technological characterization: first statements}

\section{Specificity of heat treated artefacts from Le Piage}

The NIR results confirm the use of heat treatment for lithic Solutrean industries from Le Piage. The macroscopic diagnostic, conducted on the entire Solutrean assemblage, only identified 18 heat treated shaping flakes and laurel-leaf points, in spite of the presence of a considerable number of laurel-leaf points, shouldered points and knapping waste. This observation is based solely on the presence of gloss contrast. But the number of heat-treated artefact may eventually be higher according to NIR data.

Knapping operations clearly seem to have been disrupted by the heterogeneous quality of the raw material, which appears to be responsible for several accidents (such as hinged). In this respect, the use of Tertiary chalcedony from Domme was very risky. Bifacial shaping is a complex technique for which each uncontrolled gesture can lead to the breaking of the piece (Walter et al., 2013). This choice of raw material associated with intentional heat treatment is rather difficult to comprehend, as adding a technical stage to an already complex chaîne opératoire increased the risk of failure. Did the knapper intend to facilitate shaping, or even pressure retouch, by improving the mechanical properties of the rock? This choice appears to be offset by considerable investment and risk-taking. Moreover, heating cannot compensate for raw material heterogeneities as heat treatment closes the porosity network but cannot remove inclusions and joint lines.

\section{Comparison with Laugerie-Haute published data}

From our results, it appears that bifacial preforms were heated to temperatures of about 250$300^{\circ} \mathrm{C}$. A recent study on artefacts from the Solutrean levels of Laugerie-Haute West provided similar results (Schmidt and Morala, 2018a). About forty fragments of laurel-leaves, all made from chert similar to the one studied here, were analysed by the same infrared spectroscopic protocol. The results of these analyses showed that the tools were also heated to temperatures of 250 to $300^{\circ} \mathrm{C}$ at Laugerie-Haute. Despite the relatively higher imprecision of this data due to the lower number of reference samples, the study reached the same conclusion as we do. Heating temperature ranges at both Laugerie Haute and Le Piage seem to have been very similar. Our analysis thus corroborates and refines Schmidt and Morala's (2018a) study.

Based on the results from both studies, it becomes obvious that a specific heating environment must have been necessary in order to maintain samples at temperatures of about $300^{\circ} \mathrm{C}$. Sand baths or other buried heating structures (Mandeville, 1973; Flenniken and Garrison, 1975; Purdy, 1974; Brown et al., 2009) might have allowed for enhanced temperature control at Le Piage. However, at the present time, no archaeological data confirm this hypothesis and other heating environments and techniques may have been used. 


\section{Conclusion}

Our study highlights the fragility of criteria used for the macroscopic recognition of heat treatment. Either macroscopic criteria are not pertinent and we can consequently assume that the limited quantity of macroscopically diagnostic artefacts does not reflect an archaeological reality; or conversely, the low quantity of heat-treated material could be attributable to specific situations, such as the application of a technical procedure reserved to a few experts.

Our study on Tertiary chert of heterogeneous knapping quality also shows that the widely accepted idea that siliceous materials were heat-treated in order to improve knapping aptitude should be reconsidered.

This study also provides data on the application of heat treatment by Solutrean groups. The results obtained on temperature ranges are in keeping with the results of the study carried out by Schmidt and Morala (2018) on Laugerie-Haute and point towards a controlled heating environment, rather than an open-hearth context. In the light of this, it is important to carry out more infrared spectroscopic analyses, and to combine them with diverse approaches, and in particular with experiments. These results alone are insufficient for a full description of the heating process. Experiments on specific raw materials should enable us to test the different hypotheses concerning the types of heating structures used and the required investment. Up until now, studies of heat treatment in Solutrean contexts have only been carried out on Tertiary lacustrine chert. However, at our current state of knowledge, we cannot interpret this as a specific selection strategy linked to heat treatment.

Our interpretations are limited here by the small number of artefacts in our corpus, and especially by post-depositional processes, which strongly affected the Solutrean deposits. In spite of this unfavourable context, this study enabled us to characterize the degree of investment required for the chaînes opératoires. The addition of a heating stage to highinvestment operative schemes entails clear technical and economic constraints. This "overinvestment" does not appear to be a mere quest for functional efficiency, but could rather be linked to a cultural choice. Moreover, at Le Piage, this singular investment is linked to a specific category of objects: laurel-leaf points.

Following this study, more general work has already been initiated on the management and organisation of lithic production during the recent Solutrean in the Southwest of France. It is likely that it will enable us to characterize the socio-economic context of this technical evolution. The limited geographic and temporal extension of the Solutrean provides a proper background for such an investigation.

\section{Acknowledgements}

We are indebted to C. Miller for grating access to the Agilent Cary 660 spectrometer, the Museum of National Archaeology for granting access to some of the material.

We extend sincere thanks to J.-G. Bordes and F. Lebrun-Ricalens for authorizing this study, their advice and their help during the sorting of the material (especially J.-G. B.). We also wish to thank S. Caux for her help with the petrographic characterization of the material. 
Table 1: Hydration ratio values obtained on the calibration series by dividing component 1 by component 2. [1 -column]

\begin{tabular}{|c|c|c|c|c|c|c|c|c|}
\hline & $30^{\circ} \mathrm{C}$ & $150^{\circ} \mathrm{C}$ & $200^{\circ} \mathrm{C}$ & $250^{\circ} \mathrm{C}$ & $275^{\circ} \mathrm{C}$ & $300^{\circ} \mathrm{C}$ & $325^{\circ} \mathrm{C}$ & $350^{\circ} \mathrm{C}$ \\
\hline & \multicolumn{8}{|c|}{$4545 / 4469 \mathrm{~cm}-1$ ratio $( \pm 0.01)$} \\
\hline 17873 & 0.767 & 0.769 & 0.774 & 0.783 & 0.792 & 0.803 & 0.825 & 0.853 \\
\hline 17867 & 0.760 & 0.763 & 0.766 & 0.776 & 0.783 & 0.809 & 0.851 & 0.878 \\
\hline 17871 & 0.750 & 0.775 & 0.770 & 0.769 & 0.778 & 0.802 & 0.811 & 0.832 \\
\hline 17861 & 0.772 & 0.761 & 0.783 & 0.805 & 0.792 & 0.795 & 0.817 & 0.839 \\
\hline 17861 & 0.758 & 0.761 & 0.762 & 0.769 & 0.779 & 0.788 & 0.845 & 0.872 \\
\hline 17869 & 0.764 & 0.765 & 0.771 & 0.779 & 0.776 & 0.799 & 0.805 & 0.837 \\
\hline 17865 & 0.767 & 0.761 & 0.774 & 0.786 & 0.791 & 0.813 & & \\
\hline 17874 & 0.759 & 0.756 & 0.767 & 0.775 & 0.772 & 0.791 & & \\
\hline 17866 & 0.770 & 0.772 & 0.777 & 0.786 & 0.790 & 0.795 & & \\
\hline
\end{tabular}

Table 2: Macroscopic observations and hydration ratio values 4,545/4,469cm-1 obtained on the archaeological samples. Rubefaction: + slight rubefaction; ++ strong rubefaction. [2column]

\begin{tabular}{|c|c|c|c|c|c|c|c|}
\hline Group & $\begin{array}{l}\text { Sample } \\
\text { number }\end{array}$ & $\begin{array}{l}\text { Whitening of } \\
\text { the surface }\end{array}$ & $\begin{array}{c}\text { Gloss } \\
\text { contrast }\end{array}$ & $\begin{array}{c}\text { Overall } \\
\text { gloss } \\
\text { intensity }\end{array}$ & Reddening & $\begin{array}{c}\text { Heat- } \\
\text { induced } \\
\text { fractures }\end{array}$ & $\begin{array}{c}4545 / 4469 \mathrm{~cm}- \\
1 \text { Ratio }\end{array}$ \\
\hline \multirow{31}{*}{ Group [1] } & 84 & - & - & - & - & - & $0.7516 \pm 0.01$ \\
\hline & 70 & - & - & - & - & - & $0.7541 \pm 0.01$ \\
\hline & 77 & - & - & - & - & - & $0.7599 \pm 0.01$ \\
\hline & 81 & - & - & - & - & - & $0.7614 \pm 0.01$ \\
\hline & 40 & - & - & - & - & - & $0.7620 \pm 0.01$ \\
\hline & 38 & - & - & - & - & - & $0.7622 \pm 0.01$ \\
\hline & 76 & - & - & - & - & - & $0.7624 \pm 0.01$ \\
\hline & 11 & - & - & - & - & - & $0.7650 \pm 0.01$ \\
\hline & 68 & - & - & - & - & - & $0.7662 \pm 0.01$ \\
\hline & 42 & - & - & - & - & - & $0.7671 \pm 0.01$ \\
\hline & 39 & - & - & - & - & - & $0.7673 \pm 0.01$ \\
\hline & 50 & - & - & - & - & - & $0.7678 \pm 0.01$ \\
\hline & 16 & - & - & - & - & - & $0.7680 \pm 0.01$ \\
\hline & 48 & - & - & - & - & - & $0.7683 \pm 0.01$ \\
\hline & 74 & - & - & - & - & - & $0.7687 \pm 0.01$ \\
\hline & 52 & - & - & - & - & - & $0.7688 \pm 0.01$ \\
\hline & 71 & - & - & - & - & - & $0.7691 \pm 0.01$ \\
\hline & 44 & - & - & - & - & - & $0.7700 \pm 0.01$ \\
\hline & 51 & - & - & - & - & - & $0.7700 \pm 0.01$ \\
\hline & 72 & - & - & - & - & - & $0.7702 \pm 0.01$ \\
\hline & 75 & - & - & - & - & - & $0.7703 \pm 0.01$ \\
\hline & 43 & - & - & - & - & - & $0.7705 \pm 0.01$ \\
\hline & 34 & - & - & - & - & - & $0.7746 \pm 0.01$ \\
\hline & 78 & - & - & - & - & - & $0.7763 \pm 0.01$ \\
\hline & 41 & - & - & - & - & - & $0.7773 \pm 0.01$ \\
\hline & 37 & - & - & - & - & - & $0.7779 \pm 0.01$ \\
\hline & 32 & - & - & - & - & - & $0.7799 \pm 0.01$ \\
\hline & 36 & - & - & - & - & - & $0.7805 \pm 0.01$ \\
\hline & 45 & - & - & - & - & - & $0.7808 \pm 0.01$ \\
\hline & 73 & - & - & - & - & - & $0.7836 \pm 0.01$ \\
\hline & 47 & - & - & - & - & - & $0.7889 \pm 0.01$ \\
\hline
\end{tabular}




\begin{tabular}{|c|c|c|c|c|c|c|c|}
\hline & 53 & - & - & - & - & - & $0.7907 \pm 0.01$ \\
\hline & 46 & - & - & - & - & - & $0.7926 \pm 0.01$ \\
\hline & 49 & - & - & - & - & - & $0.7927 \pm 0.01$ \\
\hline & 33 & - & - & - & - & - & $0.7934 \pm 0.01$ \\
\hline & 83 & - & - & - & - & - & $0.7941 \pm 0.01$ \\
\hline & 80 & - & - & - & - & - & $0.7953 \pm 0.01$ \\
\hline & 35 & - & - & - & - & - & $0.8001 \pm 0.01$ \\
\hline & 69 & - & - & - & - & - & $0.8005 \pm 0.01$ \\
\hline & 79 & - & - & - & - & - & $0.8059 \pm 0.01$ \\
\hline & 54 & - & - & - & - & - & $0.8113 \pm 0.01$ \\
\hline \multirow{9}{*}{ Group [2] } & 25 & Yes & - & + & - & - & $0.7636 \pm 0.01$ \\
\hline & 21 & Yes & - & + & - & - & $0.7711 \pm 0.01$ \\
\hline & 24 & - & - & ++ & - & - & $0.7798 \pm 0.01$ \\
\hline & 15 & - & - & - & ++ & - & $0.7893 \pm 0.01$ \\
\hline & 26 & - & - & ++ & - & - & $0.7915 \pm 0.01$ \\
\hline & 17 & Yes & - & - & +++ & - & $0.8017 \pm 0.01$ \\
\hline & 19 & Yes & - & - & +++ & - & $0.8032 \pm 0.01$ \\
\hline & 20 & Yes & - & - & +++ & Yes & $0.8235 \pm 0.01$ \\
\hline & 22 & Yes & - & - & +++ & - & $0.8502 \pm 0.01$ \\
\hline \multirow{19}{*}{ Group [3] } & 3 & - & Yes & + & - & - & $0.7623 \pm 0.01$ \\
\hline & 27 & - & Yes & + & - & - & $0.7676 \pm 0.01$ \\
\hline & 23 & - & Yes & + & - & - & $0.7689 \pm 0.01$ \\
\hline & 1 & - & Yes & + & - & - & $0.7695 \pm 0.01$ \\
\hline & 10 & - & Yes & + & - & - & $0.7709 \pm 0.01$ \\
\hline & 4 & - & Yes & + & - & - & $0.7722 \pm 0.01$ \\
\hline & 7 & - & Yes & + & + & - & $0.7739 \pm 0.01$ \\
\hline & 31 & - & Yes & + & - & - & $0.7761 \pm 0.01$ \\
\hline & 28 & Yes & Yes & + & - & - & $0.7774 \pm 0.01$ \\
\hline & 14 & - & Yes & + & - & - & $0.7819 \pm 0.01$ \\
\hline & 8 & - & Yes & + & + & - & $0.7850 \pm 0.01$ \\
\hline & 6 & - & Yes & + & + & - & $0.7866 \pm 0.01$ \\
\hline & 9 & Yes & Yes & + & - & - & $0.7874 \pm 0.01$ \\
\hline & 2 & Yes & Yes & + & - & - & $0.7884 \pm 0.01$ \\
\hline & 12 & Yes & Yes & + & + & - & $0.7908 \pm 0.01$ \\
\hline & 29 & - & Yes & + & - & - & $0.7908 \pm 0.01$ \\
\hline & 30 & - & Yes & + & - & - & $0.7936 \pm 0.01$ \\
\hline & 5 & Yes & Yes & + & + & - & $0.8054 \pm 0.01$ \\
\hline & 13 & - & Yes & + & + & Yes & $0.8245 \pm 0.01$ \\
\hline
\end{tabular}




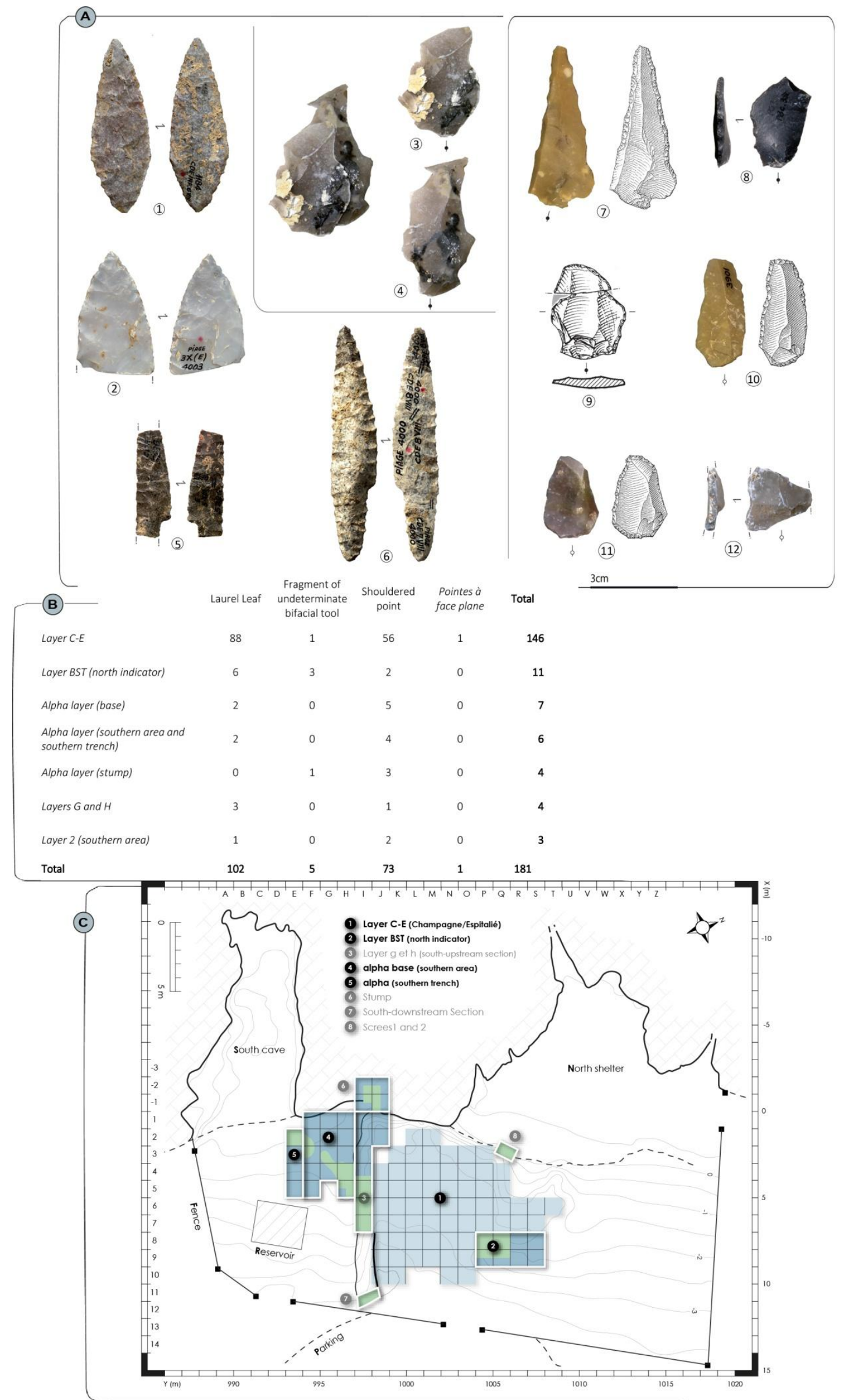

Figure 1: Le Piage, A, example of Solutrean (1 and 2: laurel leaves; 3 and 4: shaping flakes; 5 and 6 shouldered points) and Badegoulian lithic artefacts (7 to 12: Badegoulian raclettes). B: 
Counts of characteristic Solutrean remains; C: Location of the different zones with Solutrean lithic elements. [1.5-column]

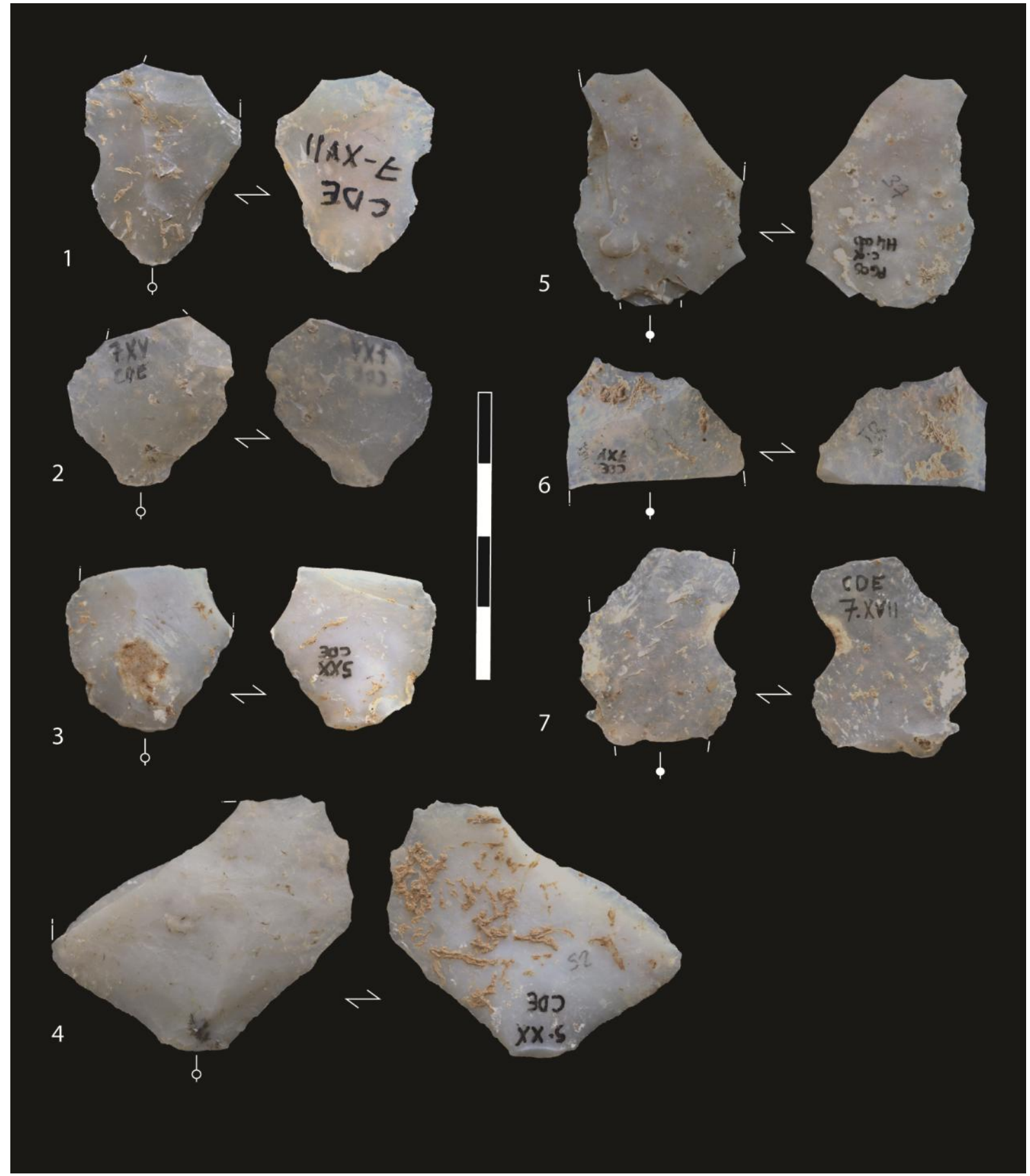

Figure 2: Shaping flakes from group 1, with no macroscopic indicator of heat treatment. [1.5column] 


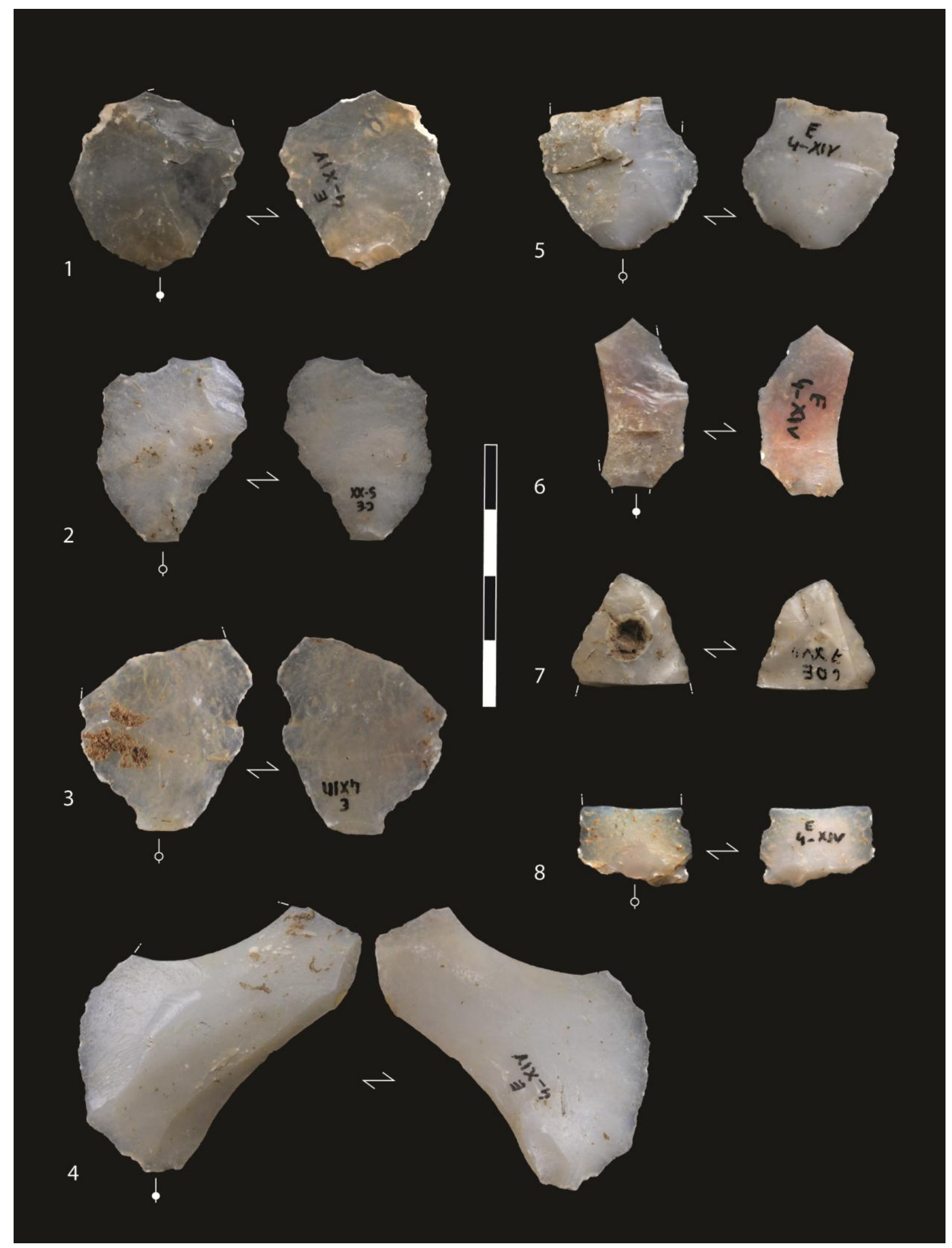

Figure 3: Heat-treated samples from group 3 with a double surface condition (alternating glossy and mat zones). 1, 2, 3, 4, 5, 6, 8: shaping flakes and 7: fragment of a bifacial piece. [1.5-column] 


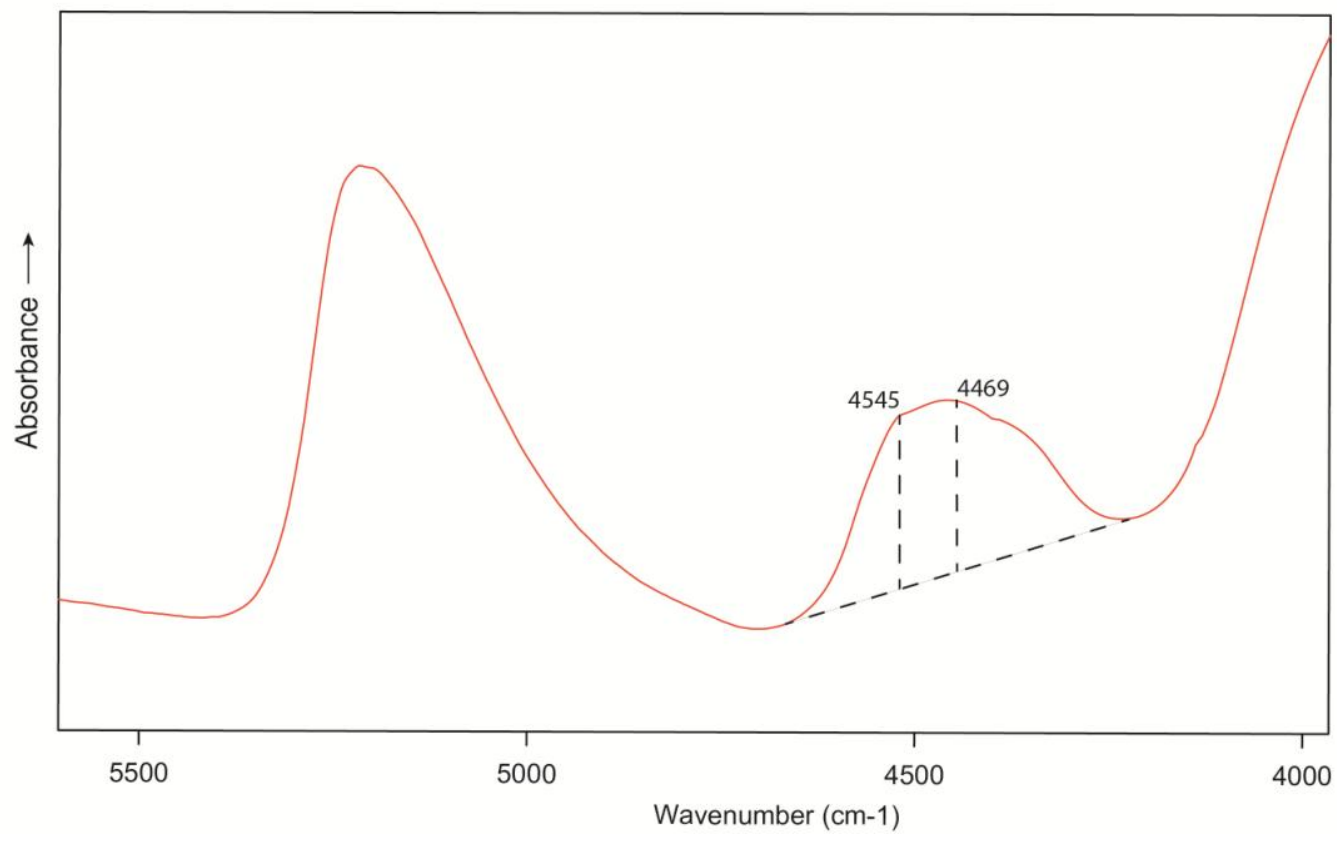

Figure 4: Example of spectrum obtained by IR spectroscopy presenting two combination bands. A first band around $5220 \mathrm{~cm}^{-1}$ produced by molecular water and a second produced by $\mathrm{Si}-\mathrm{OH}$ groups at around $4,300-4,600 \mathrm{~cm}^{-1}$. The hydration ratio is calculated by measuring the components at $4,545 \mathrm{~cm}^{-1}$ and $4,469 \mathrm{~cm}^{-1}$. [1 -column] 


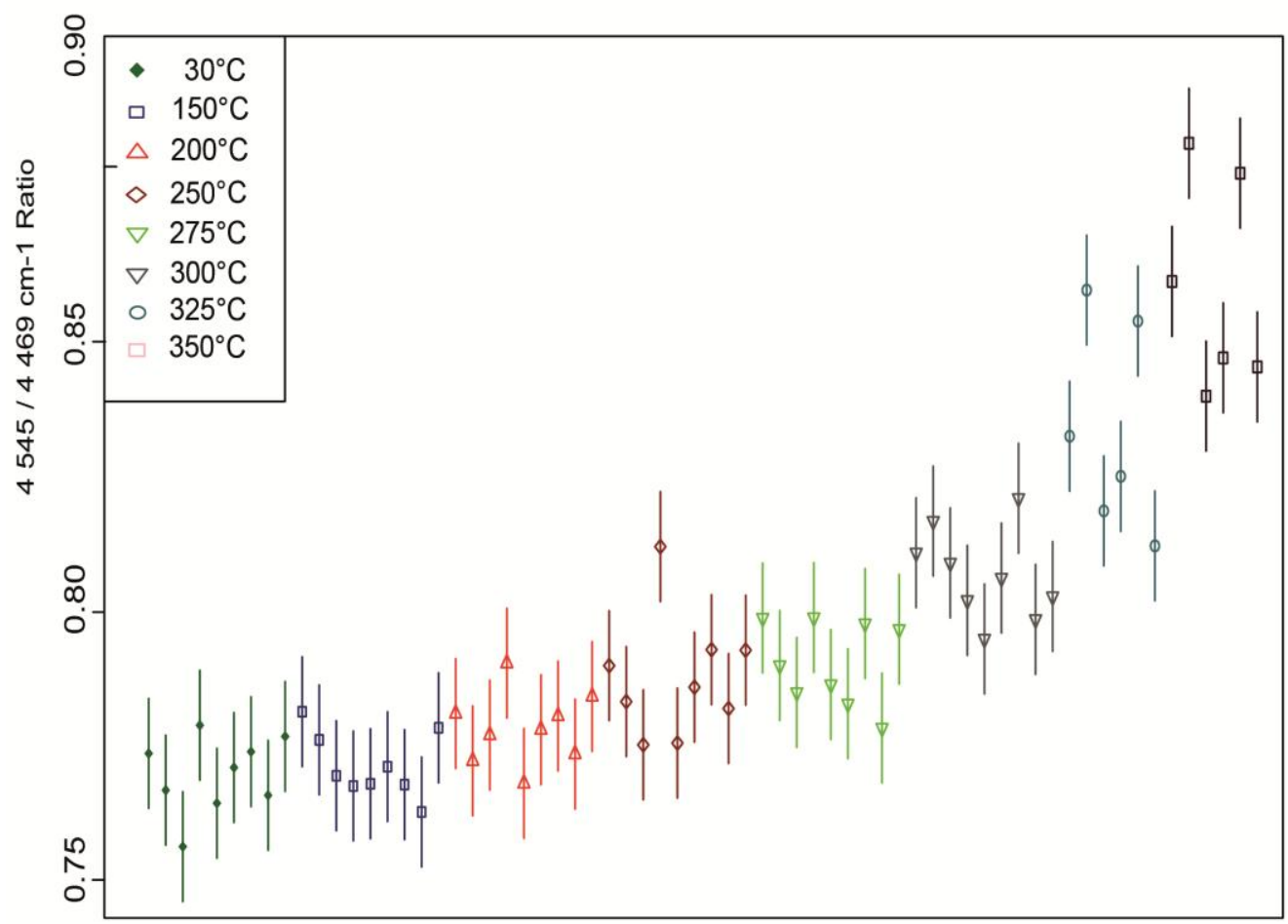

a

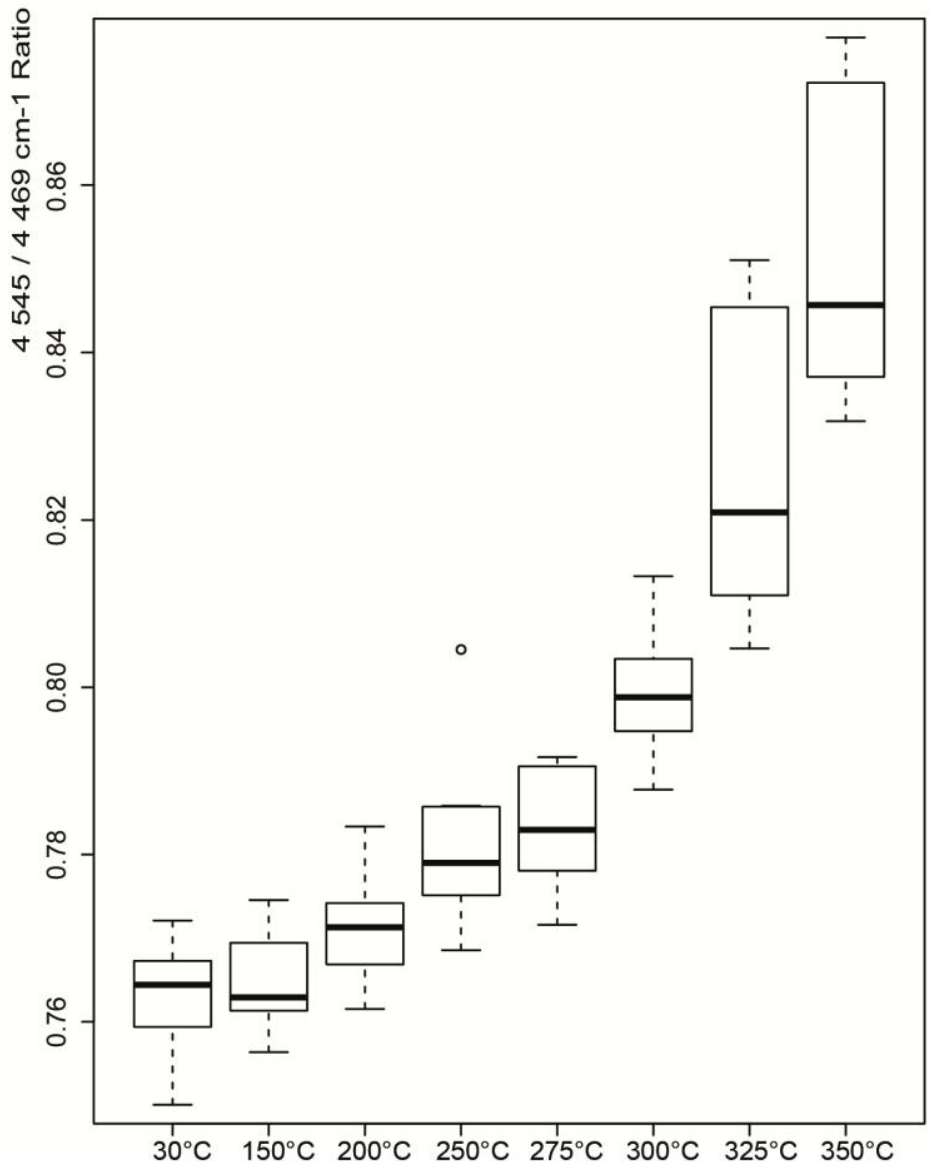

b

Figure 5: a. Calibration series with hydration ratios obtained on nine geological reference samples depending on temperature stages; b. Tukey diagram of hydration ratios per temperature stage. Ratio values at $150^{\circ} \mathrm{C}$ are almost identical to those of unheated samples (around $0.76 \pm 0.01$ ). After heating to $200^{\circ} \mathrm{C}$, the average ratio value is slightly higher and continues to increase during the following stages. Values are clearly higher in excess of $300^{\circ} \mathrm{C}$ (between 0.80 and $0.88 \pm 0.01$ ) but more dispersed. [1 -column] 
A
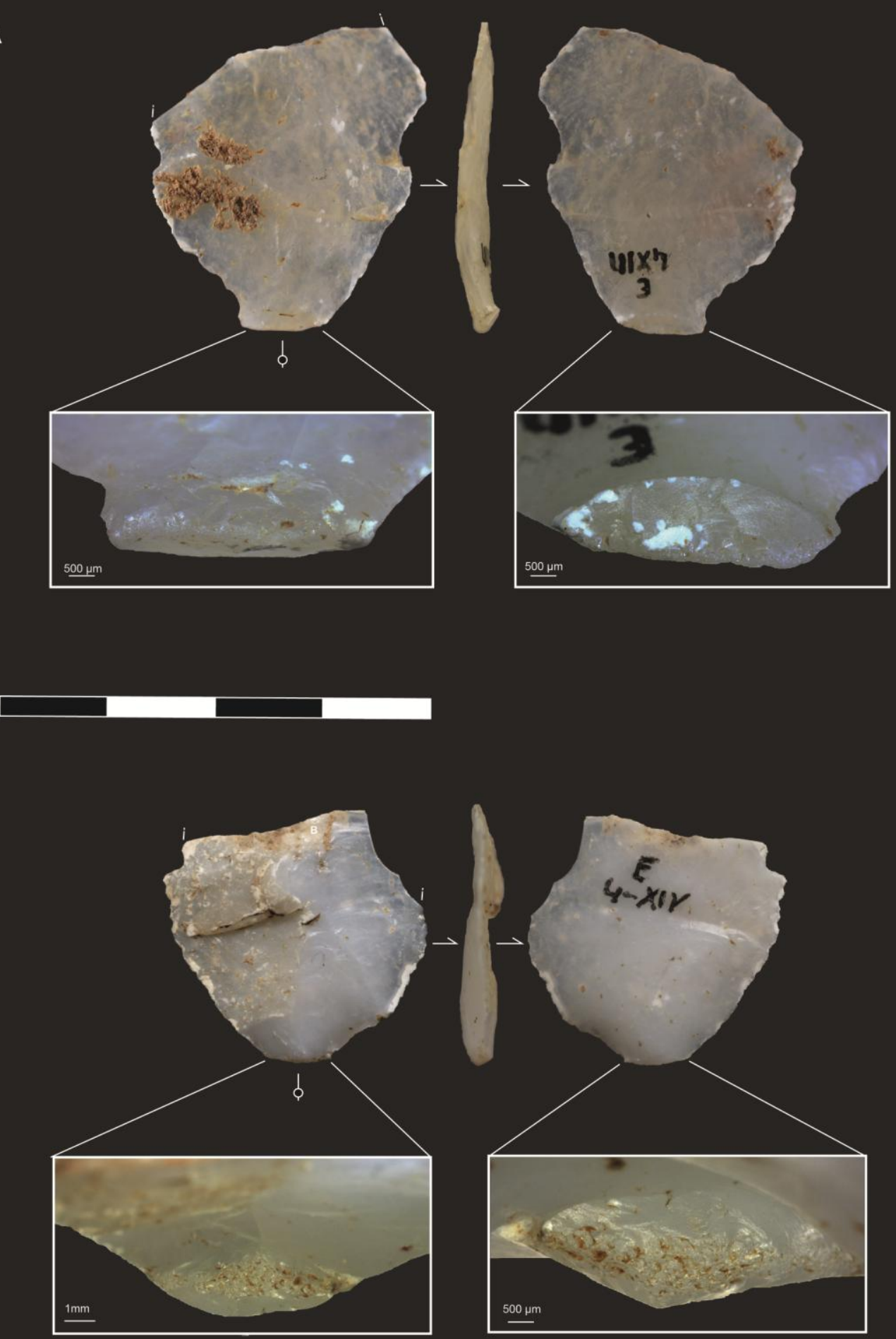

Figure 6: Comparison of hydration ratios from the archaeological corpus (a) and the calibration series based on nine geological samples heated successively to $150,200,250,275$, 300 and $350^{\circ} \mathrm{C}$ (b). [2-column] 


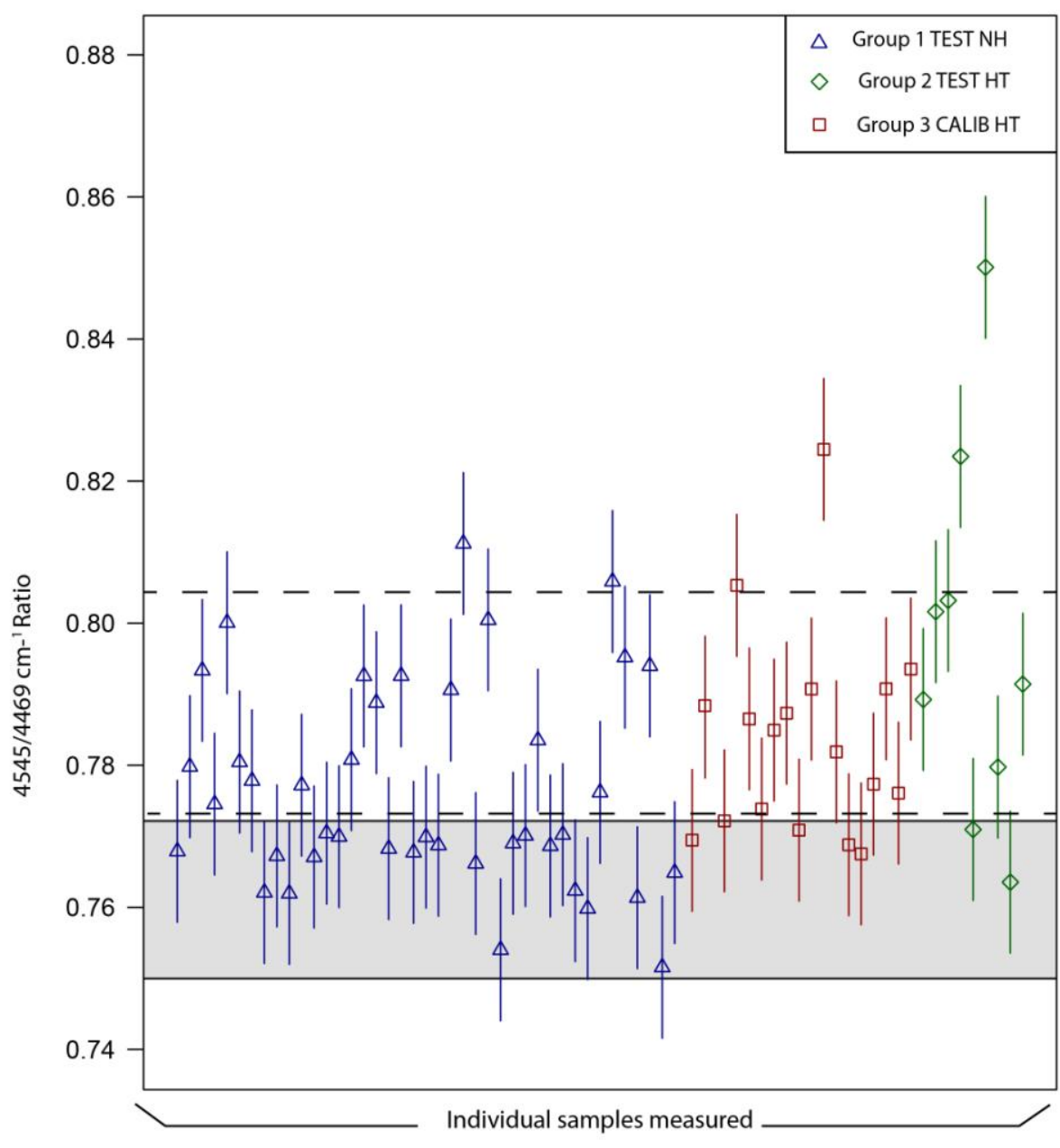

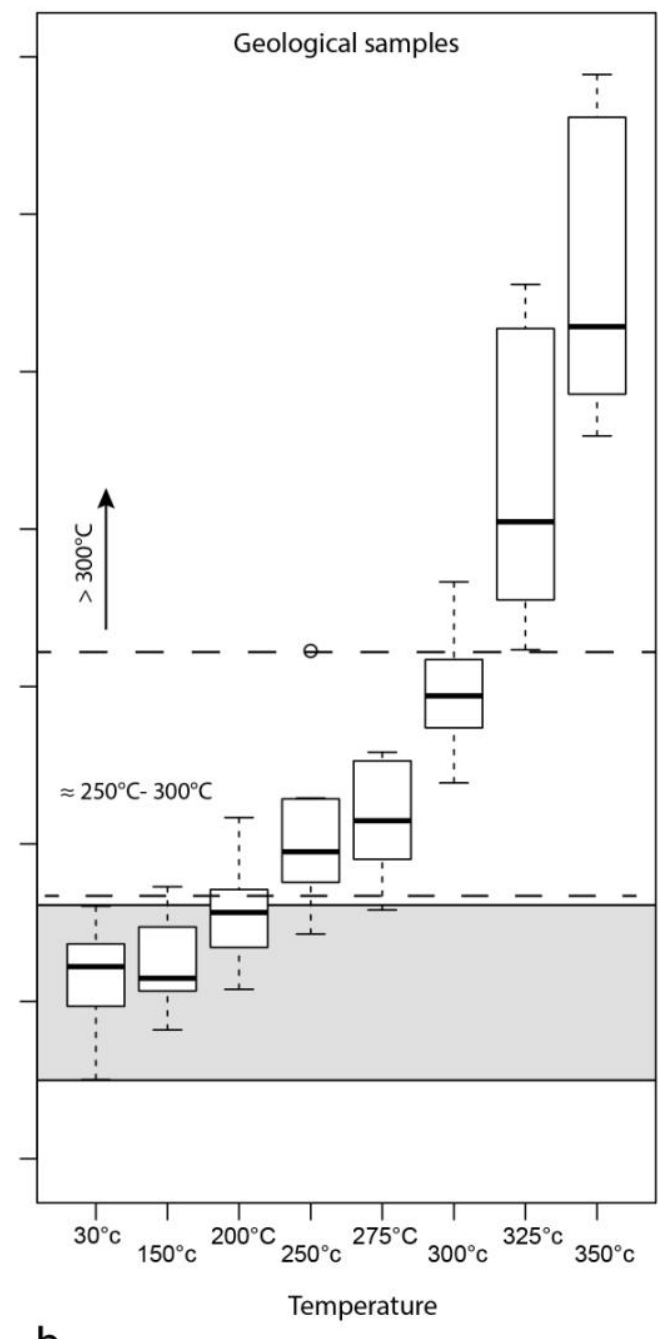

b

Figure 7: Example of two shaping flakes with indicators of heat treatment. Particular care was taken with the preparation of the removal during the bifacial shaping chaîne opératoire after the heat treatment stage. [1.5-column] 


\section{Bibliography}

1 Anderson, D.C., 1978. Aboriginal Use of Tongue River Silica in Northwest Iowa. Plains Anthropologist 23, 149-157. https://doi.org/10.1080/2052546.1978.11908888

2 Almeida, F., Brugal, J.-P., Zilhão, J., Plisson, H., 2007. An upper palaeolithic Pompeii, in: Ferreira Bicho, N. (Ed.), IV Congresso de Arqueologia Peninsular (Faro, 14 a 19 de Setembro de 2004). Centre de Estudos da Património - Universidade do Algarve, Faro, pp. 119-139.

3 Aubry, T., Almeida, M., 2013. Analyse critique des bases chronostratigraphiques de la structuration du Solutréen, in: Le Solutréen: 40 Ans Après Smith'66, Acte Du Colloque de Preuilly-Sur-Claise, 21 Octobre-01 Novembre 2007. FERACF, Tours, pp. 37-52.

4 Boix Calbet, J., 2012. El tratamiento térmico en rocas silíceas, un procedimiento técnico para la talla. Trabajos de Prehistoria 69, 37-50. https://doi.org/10.3989/tp.2012.12078

5 Bordes, F., 1967. Considérations sur la typologie et les techniques dans le Paléolithique. Quartar pl. I-VIII, 25-55.

6 Bordes, F., 1969. Traitement thermique du silex au Solutréen. bspf 66, 197. https://doi.org/10.3406/bspf.1969.10404

7 Brown, K.S., Marean, C.W., Herries, A.I.R., Jacobs, Z., Tribolo, C., Braun, D., Roberts, D.L., Meyer, M.C., Bernatchez, J., 2009. Fire As an Engineering Tool of Early Modern Humans. Science 325, 859-862. https://doi.org/10.1126/science.1175028

8 Caux, S., 2015. Du territoire d'approvisionnement au territoire culturel : pétroarchéologie et techno-économie du silex Grain de mil durant l'Aurignacien dans le Sud-ouest de la France. Archéologie et Préhistoire (Unpublished Ph.d thesis). Université de Bordeaux.

9 Collins, M.B., 1973. Observations on the thermal treatment of chert in the Solutrean of Laugerie Haute, France. Proceedings of the Prehistoric Society 39, 461-466.

https://doi.org/10.1017/S0079497X00011774

10 Collins, M.B., Fenwick, J.M., 1974. Heat Treating of Chert: Methods of Interpretation and Their Application. Plains Anthropologist 19, 134-145.

https://doi.org/10.1080/2052546.1974.11908696

11 Champagne, F., Espitalié, R., 1981. Le Piage, site préhistorique du Lot. Mémoire de la Société Préhistorique française.

12 Crabtree, D.., Butler, B.., 1964. Notes on Experiment in Flint Knapping: 1 Heat Treatment of Silica Materials. Tebiwa 7, 1-6.

13 Delagnes, A., Schmidt, P., Douze, K., Wurz, S., Bellot-Gurlet, L., Conard, N.J., Nickel, K.G., van Niekerk, K.L., Henshilwood, C.S., 2016. Early Evidence for the Extensive Heat Treatment of Silcrete in the Howiesons Poort at Klipdrift Shelter (Layer PBD, $65 \mathrm{ka}$ ), South Africa. PLOS ONE 11, e0163874. https://doi.org/10.1371/journal.pone.0163874

14 Demars, P.-Y., 1998. Circulation des silex dans le nord de l'Aquitaine au Paléolithique supérieur : l'occupation de l'espace par les derniers chasseurs-cueilleurs. Gallia préhistoire 40, 1-28. https://doi.org/10.3406/galip.1998.2156

15 Domanski, M., Webb, J.A., 1992. Effect of Heat Treatment on Siliceous Rocks Used in Prehistoric Lithic Technology. journal of archaeological science 19, 601-614.

16 Flenniken, J.J., Garrison, E.G., 1975. Thermally Altered Novaculite and Stone Tool Manufacturing Techniques. Journal of Field Archaeology 2, 125.

https://doi.org/10.2307/529623

17 Gèze, B., 1977. Aquitaine orientale. Masson. 
18 Gibaja, J.F., Clemente, I., 1997. El tratamiento térmico del sílex y sus repercusiones en la determinación de los rastros de uso. Algunos ejemplos del neolitíco en Cataluña. Revista d'Arqueologia de Ponent,153-159.

19 Griffiths, D.R., Bergman, C.A., Clayton, C.J., Ohnuma, K. et Robins, G.V., 1987. Experimental investigation of the heat treatment of flint, in, Sieveking, G.D.G. et Newcomer, M.H., The human uses of flint and chert. Proceedings of the fourth international flint symposium held at Brighton Polytechnic 10-15 April, 1983, Cambridge: Cambridge University Press, 43-52.

20 Inizan, M.-L., Roche, H., Tixier, J., 1976. Avantage d'un traitement thermique pour la taille des roches siliceuses. Quaternaria XIX, 1-18.

21 Léa, V., Roque-Rosell, J., Binder, D., Sciau, P., Pelegrin, J., Regert, M., Torchy, L., Vaquer, J., Coustures, M.-P., Roucau, C., 2012. Craft specialization and exchanges during the southern Chassey culture: an integrated archaeological and material sciences approach. Presented at the Exchange of raw materials, products and ideas in the Western Mediterranean VII-III millennium BC: Colloque international Networks in the Neolithic, 02-04 Fév. 2011, Revista Rubricatum, Barcelone, pp. 119-129.

22 Mandeville, M.D., 1973. A consideration of the thermal pretreatment of chert. Plains Anthropologist 18, 177-202.

23 Masson, A., 1981. Pétroarchéologie des roches siliceuses: intérêt en Préhistoire (Unpublished Ph.d thesis). Université Claude Bernard, Lyon, France.

24 Milot, J., Siebenaller, L., Beziat, D., Léa, V., Schmidt, P., Binder, D., 2017. Formation of Fluid Inclusions during Heat Treatment of Barremo-Bedoulian Flint: Archaeometric Implications. Archaeometry 59, 417-434. https://doi.org/10.1111/arcm.12256

25 Morala, A., 2007. Les ressources minérales : constitution d'un référentiel lithologique. In J.-G. Bordes (dir.). Le Piage (Fajoles, Lot) - Rapport d'opération de fouille triennale, 266-283.

26 Morala, A., 2017. Les silicifications des bassins versants de la Dordogne et de la Vézère: évaluation des ressources lithologiques et implications archéologiques, Musée National de Préhistoire. ed, numéro spécial Paléo.

27 Pelegrin, J., 2013. Le façonnage solutréen: des principes techniques aux savoir-faire originaux, in: Le Solutréen: 40 Ans Après Smith'66, Acte Du Colloque de Preuilly-Sur-Claise, 21 Octobre-01 Novembre 2007. FERACF, Tours.

28 Purdy, B.A., 1974. Investigations concerning the thermal alteration of silica minerals: an archaeological approach. Tebiwa 17, 37-66.

29 Purdy, B.A., Brooks, H.K., 1971. Thermal alteration of silica minerals: an archeological approach. Science 173, 322-325. https://doi.org/10.1126/science.173.3994.322

30 Renard, C., 2010. Les premières expressions du Solutréen dans le Sud-Ouest français. Evolution techno-économique des équipements lithiques au cours du Dernier Maximum Glaciaire., Oxford : J. \& E. Hedges Ltd. (BAR International Series 2070). ed.

31 Renard, C., Ducasse, S., 2015. De la rupture typologique à la fracture socio-économique. Implications sur les systèmes de mobilité entre Solutréen récent et Badegoulien dans le SudOuest français (24-21 Ka cal. BP) :, in: Les Systèmes de Mobilité de La Préhistoire Au Moyen Âge. Presented at the XXXVe Rencontres internationales d'archéologie et d'histoire d'Antibes, 14-16 octobre 2014, APDCA, Antibes, pp. 193-208.

32 Renard, C., Geneste, J.-M., 2006. De la "complexité" des productions lithiques dans le Solutréen supérieur d'Aquitaine, in: Normes Techniques et Pratiques Sociales de La Simplicité Des Outillages Pré- et Protohistoriques. Presented at the XXVIe rencontres internationales d'Archéologie et d'Histoire d'Antibes, APDCA, Antibes, pp. 119-128. 
33 Ripoll López, S., Pérez Marín, S., López Moreno de Redrojo, J.R., Martos Romero, J.A., Muñiz Pérez, M., 1997. Las estructuras de combustíon en la cueva de Ambrosio. Estudio preliminar, in: El Mon Mediterrani Després Del Pleniglacial (18.000-12.000 BP), Sèrie Monogràfica, Centre d'Investigacions Arqueológiques de Girona. Museu d'Arqueologia de Catalunya, Girona, Banyoles, pp. 399-409.

34 Roqué-Rosell, J., Torchy, L., Roucau, C., Lea, V., Colomban, P., Regert, M., Binder, D., Pelegrin, J., Sciau, P., 2011. Influence of Heat Treatment on the Physical Transformations of Flint Used by Neolithic Societies in the Western Mediterranean. MRS Proceedings 1319. https://doi.org/10.1557/opl.2011.926

35 Schindler, D.., Hatch, J.., Hay, C., Bradt, R., 1982. Aboriginal Thermal Alteration of a Central Pennsylvania Jasper: Analytical and Behavioral Implications. American Antiquity 47, 526.

36 Schmidt, I., 2015. Solutrean points of the Iberian Peninsula: tool making and using behaviour of hunter-gatherers during the Last Glacial Maximum, BAR international series. British Archaeological Reports Ltd, Oxford.

37 Schmidt, P., 2011. Traitement thermique des silicifications sédimentaires, un nouveau modèle des transformations cristallographiques et structurales de la calcédoine induites par la chauffe (Unpublished Ph.d thesis). Muséum national d'histoire naturelle, Paris.

38 Schmidt, P., 2014. What causes failure (overheating) during lithic heat treatment? Archaeological and Anthropological Sciences 6, 107-112. https://doi.org/10.1007/s12520$\underline{013-0162-3}$

39 Schmidt, P., Badou, A., Fröhlich, F., 2011. Detailed FT near-infrared study of the behaviour of water and hydroxyl in sedimentary length-fast chalcedony, SiO2, upon heat treatment. Spectrochimica Acta Part A: Molecular and Biomolecular Spectroscopy 81, 552-559.

40 Schmidt, P., Léa, V., Sciau, P., Fröhlich, F., 2013. Detecting and Quantifying Heat Treatment of Flint and Other Silica Rocks: A New Non-Destructive Method Applied to Heat-Treated Flint from the Neolithic Chassey Culture, Southern France. Archaeometry 55, 794-805. https://doi.org/10.1111/j.1475-4754.2012.00712.X

41 Schmidt, P., Masse, S., Laurent, G., Slodczyk, A., Le Bourhis, E., Perrenoud, C., Livage, J., Fröhlich, F., 2012. Crystallographic and structural transformations of sedimentary chalcedony in flint upon heat treatment. Journal of Archaeological Science 39, 135-144. https://doi.org/10.1016/j.jas.2011.09.012

42 Schmidt, P., Paris, C., Bellot-Gurlet, L., 2016. The investment in time needed for heat treatment of flint and chert. Archaeological and Anthropological Sciences 8, 839-848. https://doi.org/10.1007/s12520-015-0259-y

43 Schmidt, P., Morala, A., 2018a. First Insights into the Technique Used for Heat Treatment of Chert at the Solutrean Site of Laugerie-Haute, France: The Technique Used for Heat Treatment at Solutrean Site of Laugerie-Haute. Archaeometry 60, 885-897. https://doi.org/10.1111/arcm.12358

44 Schmidt, P., Buck, G., Berthold, C., Lauer, C., Nickel, K.G., 2018b, The mechanical properties of heat-treated rocks: a comparison between chert and silcrete, Archaeological and Anthropological Sciences, published online since 20/09/2018, DOI: 10.1007/s12520-0180710-y.

45 Terradas, X., Gibaja, J.F., 2001. El tratamiento térmico en la producción lítica: el ejemplo del neolitíco medio catalán. Cypsela 29-56.

46 Tiffagom, M., 1998. Témoignages d'un traitement thermique des feuilles de laurier dans le Solutréen supérieur de la grotte du Parpalló (Gandia, Espagne). Paléo 10, 147-161. https://doi.org/10.3406/pal.1998.1134 
47 Tiffagom, M., 2006. De la pierre à l'homme: essai sur une paléoanthropologie solutréenne, Etudes et recherches archéologiques de l'Université de Liège. ERAUL.

48 Torchy, L., 2013. De l'amont vers l'aval : fonction et gestion des productions lithiques dans les réseaux d'échanges du Chasséen méridional (Unpublished Ph.d thesis). Université Toulouse le Mirail.

49 Turq, A., 2000. Les ressources en matières premières lithiques. Paléo 2, 98-141. https://doi.org/10.3406/pal.2000.1266

50 Turq, A., Morala, A., 2013. Inventaire des silicifications du Quercy, de ses marges et des marqueurs lithologiques du nord-est aquitain: synthèse des données, in: Modalité D'occupation et Exploitation Des Milieux Au Paléolthique Dans Le Sud-Ouest de La France: L'exemple Du Quercy. Presented at the XVe Congrés mondial de l'UISPP, Supplément Paléo, Lisbonne, pp. 159-180.

51 Vigneaux, M., 1975. Aquitaine occidentale. Masson et Cie.

52 Walter, B., Almeida, M., Aubry, T., 2013. Le façonnage solutréen: des principes techniques aux savoir-faire originaux, in: Le Solutréen: 40 Ans Après Smith'66, Acte du colloque de Preuilly-sur-Claise, 21 octobre-01 novembre 2007, FERACF, Tours, pp. 135-141.

53 Zilhão, J., 1997. O Paleolítico Superior da Estremadura portuguesa. Edições Colibri, Lisboa. 